\title{
КОНКУРЕНТОСПРОМОЖНІСТЬ ВАГОНОБУДІВНИХ ПІДПРИСМСТВ ЗАЛІЗНИЧНОГО ТРАНСПОРТУ: ПРОБЛЕМИ ТА УМОВИ ЗАБЕЗПЕЧЕННЯ
}

\author{
Кузуб А.В., аспірант (УкрДУЗТ)
}

\begin{abstract}
B cтаті розглянуто причини зниження конкурентоспроможності вагонобудівних підприємств залізничного транспорту. Конкурентну ситуаџію промислових підприємств залізничного транспорту погіршує неадаптована до ринкових умов організаційна структура управління підприємством. Формування конкурентних переваг вагонобудівних підприємств в сучасних ринкових умовах запропоновано здійснювати на основі удосконалення системи управління підприємством. Визначені умови забезпечення конкурентоспроможності вагонобудівних підприємств залізничного транспорту.
\end{abstract}

Ключові слова: конкурентоспроможсність, рухомій склад, вагонобудівні підприємства, залізничний транспорт.

\section{КОНКУРЕНТОСПОСОБНОСТЬ ВАГОНОСТРОИТЕЛЬНИХ ПРЕДПРИЯТИЙ ЖЕЛЕЗНОДОРОЖНОГО ТРАНСПОРТА: ПРОБЛЕМЫ И УСЛОВИЯ ОБЕСПЕЧЕНИЯ}

\begin{abstract}
Кузуб А.В., аспирант (УкрГУЖТ)
B статье рассмотрены причины снижения конкурентоспособности вагоностроительных предприятий железнодорожного транспорта. Конкурентную ситуацию промышленных предприятий железнодорожного транспорта ухудшает неадаптированная к рыночным условиям организачионная структура управления предприятием. Формирование конкурентных преимуществ вагоностроительных предприятий в современных рыночных условиях предложено осуществлять на основе совершенствования системы управления предприятием. Определены условия обеспечения конкурентоспособности вагоностроительных предприятий
\end{abstract} железнодорожного транспорта.

Ключевые слова: конкурентоспособность, подвижной состав, вагоноремонтные предприятия, железнодорожный транспорт.

\section{COMPETITIVENESS CARRIAGE RAIL TRANSPORT: PROBLEMS AND SUPPORT OF COMPETITIVENESS}

\author{
Kuzub A.V., aspirant (USURT)
}

The article discusses the reasons for the decline in the competitiveness of the carbuilding enterprises of railway transport. The competitive situation of industrial enterprises of railway transport affects not adapted to market conditions, organizational structure of enterprise management. The formation of competitive advantages of car companies in modern 
market conditions is proposed to be based on the improvement of enterprise management system. The conditions for the competitiveness of car-building enterprises of railway transport.

Causes of decline in the competitiveness of rail transport wagons. Today the state Carriage Building industry is unsatisfactory. The competitive situation of rail transport industry degrades not adapted to market conditions, organizational structure management. To ensure a high level of efficiency of wagon building companies in the current market conditions should make the improvement of enterprise management system. Proposed terms of ensuring the competitiveness of rail transport wagons.

Keywords: competitiveness, rolling stock, carriage repair enterprises rail.

\section{Постановка}

проблеми.

Вагонобудівні підприємства залізничного транспорту $є$ основою розвитку залізничного транспорту України, оскільки забезпечують інноваційні перетворення в залізничній галузі шляхом виробництва новітніх транспортних засобів. Однак складна політична ситуація, втрата традиційних ринків збуту, застарілі виробничі потужності, відсутність інвестиційних ресурсів, наявність конкурентів, що максимізують всій потенціал, за рахунок поширення оптимізаційних зав'язків, призводять до втрати конкурентних позицій вітчизняних вагонобудівних підприємств на ринку транспортної продукції, що негативно впливає і на фінансово-економічний стан підприємств. Подолання кризових явищ вагонобудівних підприємств потребує формування якісно нового підходу до забезпечення їх конкурентоспроможності.

\section{Аналіз основних досліджень $i$} публікацій. Питання формування забезпечення конкурентоспроможності підприємств досліджено в роботах таких економістів, як Б.Г. Циган [2], Н.3 Криворучко [8], М. Портер [10], В.П. Бугаєв [9], Л.Н. Качаліна [5], Р. Фатхутдінов [4] та ін. Дослідження

функціонування та

проблем конкурентоспроможності вагонобудівних підприємств та транспортної галузі, проводили такі вітчизняні вчені, як: В.Л. Дикань [3], М.І. Данько [7], Ю.М. Уткіна [11], Н.С. Каличева [12], Т.В. Нескуба [6] та інші. Проте, незважаючи на наявність наукових публікацій у цій галузі, питання забезпечення конкурентоспроможності вагонобудівних підприємств України в умовах реформування залізничного транспорту та розвитку євроінтеграційних процесів потребують більш глибокого дослідження.

Метою cmami є дослідження стану вагонобудівних підприємств залізничного транспорту, основних проблем та умов забезпечення їх конкурентоспроможності.

Виклад основного матеріалу. В сучасних умовах господарювання, конкуренція являє собою суперництво між виробниками товарів та послуг за кращі, економічно вигідні умови виробництва та реалізації продукту для задоволення потреб споживачів [3]. Місце підприємства на ринку, його ефективне функціонування обумовлено рівнем конкурентоспроможності підприємства, який характеризується можливості підприємства завойовувати та утримувати конкурентні позиціі на внутрішньому та зовнішньому ринках.

Основними показниками, які визначають конкурентоспроможність підприємства $є$ висока виробнича ефективність, швидкість подачі продукції на ринок, якість продукції, собівартість продукції.

Вагонобудівні підприємства $\epsilon$ індустріальною базою залізничного транспорту України, діяльність яких направлена на забезпечення високоефективним рухомим складом, що 
дозволить швидко і безперебійно доставляти будь-які види вантажів. Однак, сьогодні на підприємствах спостерігається поширення кризових явищ, погіршення їх фінансово - економічного стану. Це обумовлено скороченням об'ємів виробництва. Так за останні 2 роки обсяг виробництва скоротився на $25,5 \%$, що призвело до зменшення прибутку [4].

Всього у вагонобудівній галузі України працює 18 підприємств. Найбільшими є: ВАТ «Крюківський вагонобудівний завод», ВАТ «Дніпровагонмаш», ВАТ «Стаханівський вагонозавод», ВАТ «Азовзагальмаш». Більшість із перерахованих заводів виробляє вантажні вагони.

До 2014 року близько 80\% продукції цих підприємств експортувалося до Росії, але втрата економічних зв'язків 3 Російською Федерацією призвели до втрати цього ринку, відбулося скорочення обсягів виробництва, що негативно вплинуло на вагонобудівну галузь України. Інші 20\% продукції експортувалося до Азербайджану, Німеччини, Угорщини, Туреччини та інших країн. 32014 р. підприємства працювали 3 такими замовниками, як ПАТ «Українська залізниця», меткомбінат «Азовсталь», «Укррефтранс» [5].

Основним потенційним споживачем продукції вагонобудівних підприємств є ПАТ «Українська залізниця». Однак, реформування залізничного транспорту, кризовий стан галузі, відсутність фінансових ресурсів, високий рівень корумпованості, недобросовісне виконання договірних домовленостей, обумовлюють низькі обсяги закупівель транспортних засобів ПАТ «Українська залізниця», низький рівень співпраці залізниць 3 вітчизняними вагонобудівними підприємствами.

До причин зниження конкурентоспроможності промислових підприємств слід віднести [6]:
- використання

старого обладнання, яке практично не оновлюється, у

ремонтному виробництві;

- застосування

застарілих

технологій виробництва;

- зростання

собівартості

продукції;

- зниження якості продукції;

- використання застарілої моделі управління підприємством;

- недосконалість організаційної

структури;

- зниження кваліфікації

працівників;

- не ефективне використання якісних і кількісних показників систем управління підприємством;

- підвищення рівня залежності підприємств від постачання матеріалів i комплектуючих:

- відмова від спеціалізації підприємства на ремонті одного або двох типів вагонів;

- нестача власних коштів на закупівлі необхідних матеріалів, вузлів, колісних пар та ін.

Конкурентну

ситуацію

вагонобудівних підприємств залізничного транспорту значно мірою погіршує неадаптована до ринкових умов організаційна структура управління. Діюча організаційна система вагонобудівного виробництва базується на принципах самозабезпечення, що в умовах конкурентного середовища негативно впливає на оперативність прийняття управлінських рішень.

До основних недоліків такої системи управління слід віднести [8]:

1) не зацікавленість працівників підприємств у наданні якісного ремонту вагонів, оскільки вантажні вагони не приписані до конкретної залізниці чи депо;

2) відсутність економічної зацікавленості у ремонті вагонів з великим обсягом ремонтних робіт, оскільки 
використовується затратний принцип їх фінансування;

3) застосування системи централізованого фінансування, що призводять до непокриття потреби підприємства у сучасному обладнанні, запасних частинах.

Вагонобудівні підприємства як об'єкт управління мають свої ознаки: необхідність вирішення не тільки окремих інженерно-економічних проблем, а й проблем довгострокового планування та прогнозування розвитку матеріальнотехнічної бази, економічно обгрунтованого нормування оборотних засобів; різноманітність структурних підрозділів, високий ступінь централізації системи управління, взаємопов'язаність та необхідність синхронізації дій.

Однією 3 умов забезпечення конкурентоспроможності вагонобудівних підприємств пропонуємо виділити удосконалення системи управління за рахунок постановки чітких цілей, завдань, формування ефективної організаційної структури управління, визначення технології управління та забезпечення виробництва висококваліфікованим персоналом (рис. 1).

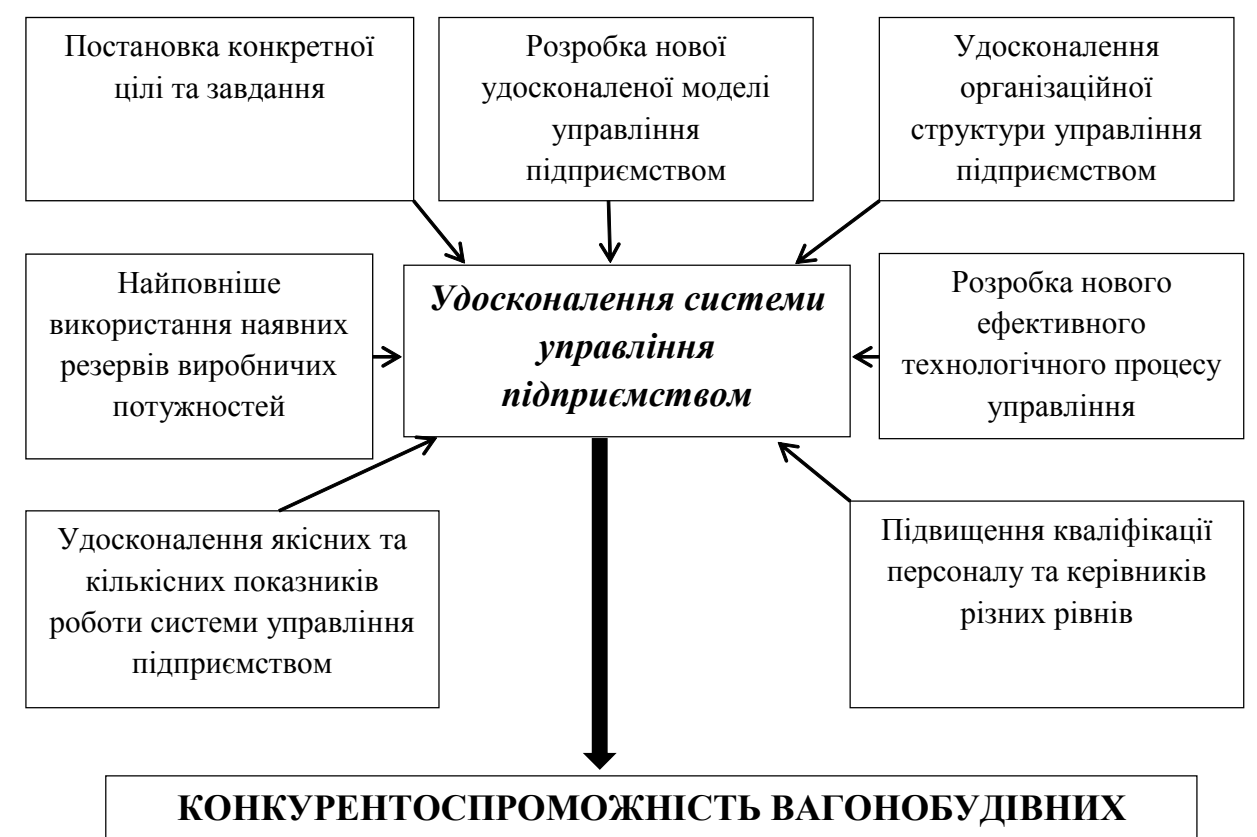

Рис. 1. Умови забезпечення конкурентоспроможності вагонобудівних підприємств залізничного транспорту

Для досягнення високого рівня ефективності діяльності вагонобудівних підприємств в сучасних ринкових умовах, удосконалення системи управління підприємством передбачає:

1) формування нових конкурентних переваг які дозволять завоювати конкурентні позиції на ринку (удосконалення швидкості подачі продукції на ринок, поліпшувати якість вагонів за рахунок удосконалення технологічного процесу, зменшувати собівартість);

2) визначення факторів зовнішнього середовища та їх впливу на конкурентоспроможність;

3) оптимізацію системи управління за рахунок спеціалізації підприємства та відновлення потокового методу ремонту; 
4) створення раціональної організаційної структури та механізму управління підприємствами;

5) підтримку галузі з боку держави, за рахунок прямого державного фінансування.

Висновки. На сьогоднішній день стан вагонобудівних підприємств залізничного транспорту є незадовільним, тому забезпечення конкурентоспроможності цих підприємств $\epsilon$ важливим аспектом розвитку залізничного транспорту.

$$
\text { Для }
$$

забезпечення конкурентоспроможності вагонобудівних підприємств залізничного транспорту необхідно удосконалювати систему управління підприємством на основі: розробки нової удосконаленої моделі управління підприємством; удосконалення організаційної структури управління підприємством; розробки нового більш ефективної технології процесу управління; постановки конкретних цілей та завдання; найповнішого використання наявних резервів виробничих потужностей; удосконалення якісних та кількісних показників роботи системи управління підприємством; підвищення кваліфікації персоналу та керівників різних рівнів.

\section{СПИСОК ЛІТЕРАТУРИ}

1. Про затвердження планів заходів Укрзалізниці з реформування галузі : наказ Міністерства Інфраструктури України від 20 січня 2012 р. № 016-ц [Електрон. ресурс] - Режим доступу: http://www.uz.gov.ua

2. Б.Г. Цыган Вагоностроительные конструкции (изготовление, модернизация, ремонт)/ Цыган Б.Г., Цыган А.Г.. Кременчуг: Изд-во "Кременчуг", 2006.- 751 c.

3. Дикань В.Л. Обеспечение конкурентоустойчивости предприятия: монография / В.Л. Дикань. - Харьков: Основа, 1995. - 160 с.
4. Фатхутдинов Р.А. Управление конкурентоспособностью организации: учебник / Р.А. Фатхутдинов.- М.: Изд-во Эксмо, 2005. - 544 с.

5. Екпозиція національних виробників товарів легкої промисловості України [Електронний ресурс] - Режим доступу:

http://www.ukrexport.gov.ua/ukr/prom/ukr/27. html

5. Качалина

Л.Н. Конкурентоспособный менеджмент / Л.Н. Качалина. - М.: Изд-во Эксмо, 2006. $464 \mathrm{c}$.

6. Нескуба, Т. В. Стратегія розвитку підприємства вагоноремонтного господарства залізничного транспорту України в умовах реформування галузі / T. В. Нескуба. //Вісник економіки транспорту і промисловості 2009. - №26 C.122-125.

7. Дикань В.Л. Повышение эффективности функционирования естественных монополий в условиях рынка (по материалам железнодорожного транспорта): монографія. / В.Л. Дикань, М.I. Данько, О.В. Шраменко - Х.: УкрДАЗТ, 2010. - 168 c

8. Криворучко Н. 3. Вагонное хозяйство / Н. 3. Криворучко. - М.: Трансжелдориздат, 1961. - 320 с.

9. Бугаев В. П. Методика распределения базы деповського ремонта грузовых вагонов по сети железных дорог / В. П. Бугаев, В. И. Сенько. // Совершенствование конструкции и ремонта вагонов : тр. Белорус. ин-та инж. ж.-д. трансп. - Гомель, 1973. - Вып. 96. - С. 3550 .

10.Портер М. Конкуренция: пер. с англ. / Майкл Портер. - М. : Изд. Дом «Вильямс», 2005. - 608 с.

$$
\text { 11.Уткіна Ю.М. Резерви }
$$
забезпечення якості на вагоноремонтних підприємствах залізничного транспорту / Ю.М. Уткіна // Вісник економіки транспорту i промисловості: збірник 
наукових праць.- Харків, УкрДАЗТ.-2008.№24.-C.75-78.

12. Каличева Н.Є. Організація управління на підприємствах залізничного транспорту в сучасних умовах /
Н.Є. Каличева // Вісник економіки транспорту i промисловості: збірник наукових праць.-Харків, УкрДАЗТ.-2014.№45.-C.167-170.

Стаття надійшла: 19.09.16р.

УДК 338.47:656.2

\title{
ВИРОБНИЧІ ЗАГРОЗИ ЕКОНОМІЧНІЙ БЕЗПЕЦ ПІДПРИЄМСТВ ЗАЛІЗНИЧНОГО ТРАНСПОРТУ
}

\author{
Лапін П.В., здобувач (ДУІТ)
}

У статті обтрунтовується використання показників залізничних транспортних подій, незбереження вантажів, непов'язаних із крадіжками, та показників пожеж у рухомому складі та стаціонарних об'єктах в якості загроз економічній безпеці підприємств залізничного транспорту виробничого характеру. Показано, щзо найбільшу частку економічних збитків для залізнииі серед запропонованих показників становлять пожежі на об'єктах залізничної інфраструктури, що визначає напрямки подальших досліджень та проведення роботи із забезпечення протипожежної безпеки.

Ключові слова: залізничний транспорт, несанкціоноване втручання, транспортна подія, пожежа, загрози економічній безпеці, збитки.

\section{ПРОИЗВОДСТВЕННЫЕ УГРОЗЫ ЭКОНОМИЧЕСКОЙ БЕЗОПАСНОСТИ ПРЕДПРИЯТИЙ ЖЕЛЕЗНОДОРОЖНОГО ТРАНСПОРТА}

\section{Лапин П.В., соискатель (ГУИТ)}

В статье обосновывается использование показателей железнодорожных транспортных происшествий, несохранности грузов, не связанных с кражами, и показателей пожаров в подвижном составе и стационарных объектах в качестве угроз экономической безопасности предприятий железнодорожного транспорта производственного характера. Показано, что наибольшую долю экономического ущерба для железной дороги среди предложенных показателей составляют пожары на объектах железнодорожной инфраструктуры, что определяет направления дальнейших исследований и проведения работ по обеспечению противопожарной безопасности.

Ключевые слова: жселезнодорожный транспорт, несанкционированное вмешательство, транспортное происшествие, пожар, угрозы экономической безопасности, ущерб.

(C) Лапін П.В.

Вісник економіки транспорту і промисловості № 55, 2016 